Article

\title{
The Anti-Politics Machine of Green Energy Development: The Moroccan Solar Project in Ouarzazate and Its Impact on Gendered Local Communities
}

\section{Sarah Ryser}

Institute of Social Anthropology, University of Bern, 3000 Bern 9, Switzerland; sarah.ryser@anthro.unibe.ch

Received: 7 February 2019; Accepted: 10 June 2019; Published: 20 June 2019

check for updates

\begin{abstract}
The Moroccan Agency for Sustainable Energy (MASEN) established one of the largest solar energy projects in the world through a public-private partnership. It is on communal land previously owned by a Moroccan Amazigh (Berber) clan in the Ghessate rural council area, $10 \mathrm{~km}$ away from Ouarzazate. The land for the energy project comprises a surface area of more than 3000 hectares. This large-scale land acquisition has led to the loss of access to common-pool resources (land, water, and plants), which were formerly managed by local common property institutions, due to its enclosure, and the areas themselves. This paper outlines how the framing of the low value of land by national elites, the state administration, MASEN, and the subsequent discourses of development, act as an anti-politics machine to hide the loss of land and land-related common-pool resources, and thus an attack on resilience-we call it in our scientific discipline a process of 'resilience grabbing' (Resilience is the ability of a person and/or a household to restore basic livelihood capacities after shocks and hazards. Such capacities need to be available over time and remain high for the unit (household, community) to be resilient), especially for women. As a form of compensation for the land losses, economic livelihood initiatives have been introduced for local people based on the funds from the sale of the land and revenue from the solar energy project Noor Ouarzazate. The loss of land representing the 'old' commons is-in the official discourse-legitimated by what the government and the parastatal company call the development-related 'fruits of growth', and should serve as 'new forms of commons' to the local communities. The investment therefore acts as a catalyst through which natural resources (land, water, and plants) are institutionally transformed into new monetary resources that local actors are said to be able to access, under specific conditions, to sustain their livelihood. There are, however, pertinent questions of access (i.e., inclusion and exclusion), regulation, and equality of opportunities for meeting the different livelihood conditions previously supported by the 'old' commons.
\end{abstract}

Keywords: resilience and commons grabbing; gender; sustainable energy; development policy

\section{Introduction}

When analysing the Moroccan 'green energy dream', the policy on developing green energy production, especially solar power in the context of large-scale land acquisition (LSLA), is meaningful because it focuses on a green energy project in a so-called 'no man's land' or 'wasteland' (not being productively used). Anthropological research is rather uncommon in the (green) energy domain. The LSLA is in no man's land and research will unearth how different actors in the research area either benefit or lose directly or indirectly from the LSLA project. The various elements, the uncertainties, pro and contra positions for and against LSLA generating solar power, and the dynamic multifaceted complex context in the Moroccan case study reflect the reality, and include different sentiments and 
opinions from all kinds of actors with their own views of the situation in the research area. The author sees the various elements in this research as very important. The results of analysing the LSLA in Morocco and the effects of the Noor Ouarzazate solar project are not simply 'negative' or 'positive', but demonstrate a very dynamic and complex context. There are ambivalent views towards the complexity of problems brought by the Noor Ouarzazate solar project, alongside the production of green solar energy - therein lies the significance of the paper. People claim how proud they are that the project is on their land and how important the infrastructure investments are. They talk about their relationship, the connection to King Mohammed VI and the King's national investment policies, but they also hint at the loss of their land, and feelings of sadness when looking at the enclosure.

Even the pathways we used before are no longer there! Once, we went with our animals to the other side of the plateau and were able to come back home in the evening. But now we cannot because it's closed. We also used to go to Ouarzazate by mule or donkey only in $2 \mathrm{~h}$ and $45 \mathrm{~min}$. Now you cannot pass anymore. We didn't benefit from this. (Herder, Tasselmante, Morocco, excerpt from an interview conducted in April 2016)

Herders explained why it was important to go from one riverbed to the other and come back in the evening with the herd. There is little feed, and the animals have to move around the whole day and find new food. It is important for herders to come home in the evening and to do some work in their house or garden. When they cannot walk across the area because it is fenced off, making a detour with the goats and sheep takes too much time. The pathways were also important for travel to Ouarzazate, which has a bigger local market and many important public amenities. The herders also mention the interpretation or classification of the land as 'wasteland', which is not adequate in their view, because there are many different local actors for whom the land was certainly not wasteland before it was used for investment. Such contradictions and ambiguity provide an important part of the analyses, showing the ambivalent nature and complexity leading to the different perceptions of people involved in different ways. LSLA green grabbing ${ }^{1}$ examples have to be contextualised and green energy infrastructure investments must be connected to all debates about fighting climate change, as well as the discourse on the effects of global warming, generating sustainable energy, and SDGs (sustainable development goals). Climate change and global warming are linked not only to energy consumption, but also to biodiversity. In the Moroccan case, the Noor Ouarzazate solar project is framed as a 'win-win-win' ${ }^{2}$ situation for all actors involved and is therefore narratively legitimised. The "deployment of colonial legal instruments for territorial dispossession" [3] was used to acquire the land necessary for national green energy development and this will continue also in the future (see Reference [3]). As shown elsewhere [4], the example of the Noor Ouarzazate solar project, built on the common land of the Amazigh Ait Ougrour, illustrates how a large-scale land acquisition (LSLA) project for generating green energy "impacts existing power constellations and gender relations governing access to land and land-related, common-pool resources (pasture, plateau products, e.g., plants for medicinal or domestic use, and animal fodder) and leads to a loss of these resources previously managed as common property" [4]. It is argued that this loss is compensated for by payments from the state and the company MASEN (Moroccan Agency for Sustainable Energy) and state-driven development programmes "as well as by contributions from the operating company's Corporate Social Responsibility Projects (CSR)" [4]. The state, national, and international donors argue that "these projects provide a form of 'new commons', which promise to deliver on-going revenues and development" [4]. MASEN [5,6] transferred instalments to a special account belonging to the

1 'Green grabbing can be understood as part of the vigorous debate on 'land grabbing' more generally, a debate which already highlights instances where 'green' credentials are called upon to justify appropriations of land for food or fuel [1] in [2] (p. 2)' and in this case study for green solar energy plants.

2 (1) It makes worthless parts of the country valuable; (2) It makes Morocco a greener country, helping the world fight against climate change and global warming; and (3) It brings development for marginalised groups such as rural women and men. 
Ministry of the Interior, who holds the money on behalf of the Ait Ougrour community ${ }^{3}$. The DAR ${ }^{4}$ manages the account and decides with the Community Supervisory Council how the money will be used. In this way-according to the discourse of the administration-local community expectations are better addressed. Project designers claim that they create development opportunities for local people, and specifically for women: "By creating opportunities for the redistribution of access to 'new' resources, such as job opportunities or benefits from CSR schemes, they often come at the cost of common-pool resources for women. These new benefits are often labelled in general terms, such as the 'development' that LSLA investments provide to local areas, but the kind of development they provide needs to be analysed from a local perspective" [4]. As we will see in this article, one of the key questions is, "do the Amazigh people need this kind of development?" The focus of this paper will also be, as the title suggests, on how the process of the anti-politics machine [7] is used by the national leaders who shape the policy, and subsequently the acquisition of the land for the project. The author will furthermore outline the socio-economic impacts of the project, such as changes to the local people's access to the land due to the investments and the discourses used as a strategy against opposition and objection.

\section{Theoretical Perspective}

With a neo-Marxist-inspired focus on feminist political ecology at a micro-level in the research, the article explains the relationships between the political, economic, and social factors, and environmental issues and changes. It tries to shed light on the Moroccan discourse on ethnic identity and 'tribal heroism'. It will explain the socio-ecological effect of related investment with the example of gendered initiatives for women's empowerment at a local level.

These approaches stress the socially, culturally, historically, and politically constructed nature of gender relations, and the interaction of gender with other socially important variables, such as age, marital status, class, ethnicity, and migratory status. Feminist political ecology introduces gender as a critical variable in shaping resource use, access, and control, including environmental rights and responsibilities, and processes of ecological change (see Reference [8]). It shows that gendered rights and responsibilities can be very complex (see, for example, Reference [9]). Environmental issues are approached from the lens of social, distribution, and knowledge conflicts. The focus is clearly on power structures and women's and men's interrelated strategic interests that determine resource access and control over resources (see References [8,10-12]). The gender, environment, and development (GED) approach is also useful for analysing relationships between gender and the environment. It consists of the feminist political ecology approach outlined above (see References $[8,10,11]$ ), and feminist environmentalism, which focuses more on the material aspects of the relationship between gender and the environment, associated most notably with Bina Agarwal $([13,14])$. Women, in this case study, are also in charge of household and food security (see, for example, Reference [15])—a role that also comes under stress during environmental and institutional change. A focus on care work, as one of the domains in which gender inequalities are the most pronounced and hardest to change, is therefore extremely important for any study of gender relations (see Reference [16]). From a feminist political ecology perspective, this will mean assessing how this domain of control by women changes as a result of the changing environment and the institutions governing access to land resources due to investment. This feminist political ecology perspective is a good addition to the new institutionalism approach in social anthropology, in which mechanisms such as externally shaped changes in relative prices for land

3 In accordance with Article 6 of the Royal Dahir of 19 March 1951, by a commission of expertise comprised of the following members: (i) the pasha or caïd as president; (ii) a local representative of the Ministry of Finance; (iii) local representatives of the Ministries of Agriculture and Commerce and the High Commission for Water and Forests; and (iv) a local representative of the Ministry of Public Works. The community tutelage council will decide on the use of funds from the sale of land to the benefit of the community of Ait Oukrour Toundout. (Moroccan Agency for Solar Energy (MASEN [6] Plan d'Acquisition de Terrain).

DAR: Direction des Affaires Rurales/Directorate of Rural Affairs. 
and resources have an impact on local gendered bargaining power constellations of actors, the way these are able or not, via their changed power, to select the institutional setting they prefer, and the way this is organised and legitimised ideologically. Ferguson's anti-politics machine [7] relates to this process by legitimating investment via green development discourse, and hides the grabbing process which—as a feminist political ecology would show—affects men and women differently, as well as the identity of ethnic groups.

Following Lila Abu-Lughod's work [17], Do Muslim Women Need Saving?, the author also formulated the questions, "do Amazigh people need this kind of 'development' and such 'modernity'?" and "do women need empowerment?" National and international discourses on modernity focusing on development are linked to promoting green energy projects, which are also defined as gendered, meaning that both women and men should benefit from the development in general but also from the specific development projects that constitute part of the LSLA. If the discourses claiming that rural areas in Morocco or the Amazigh ${ }^{5}$ people need development/modernity are credible, then its founding is easier to legitimise. It is all connected, and insights from feminist discourse into development will help to shed light on questions about who gets to decide what is necessary or to propose and choose the CSR projects constituting the so-called development of the rural Amazigh woman, and who benefits from the existing source of capital. These are all linked to theoretical insights from feminist political ecology about who gains and who loses, but also show how this is shaped in an anti-politics machine manner in combination with the discourse on state modernity and modern sustainable green development, which also evokes national and local identities.

\section{Methodology}

The research was carried out in the surrounding area of the largest solar project in Morocco, situated close to Ouarzazate (see Figure 1). Fieldwork comprised more than 12 months of data collection, between 2015 and 2018. As a qualitative research project, the research relied heavily on participant observation in combination with narrative interviews, informal conversations with experts, associations, and non-governmental organisation (NGO) representatives, and focus group discussions with both men and women (e.g., sex workers, local women, solar project workers, and others). This was then augmented with in-depth biographies and secondary data from a literature review.

The research process first involved an exploratory phase at the beginning of July 2015, when I travelled to the study area to make initial contact with local actors and tested the data collection tools. This was followed by a second phase of intensive data collection a month later, after all adjustments to the questionnaire were completed and updated. A prolonged period of stay in the local community with members of the extended family opened many doors during the research and granted access to the local community members. When I arrived in Ouarzazate together with my family-two small children and my Moroccan/Swiss husband (of Arabic/Berber origin) - we first had to find a place to stay and a school for the children. Of course, the summer was very hot and dry, in the area of a solar energy project, but we had underestimated the extent of this. The weather forced many people to stay inside their houses, a fact compounded by windy, dusty conditions on the plateau and the fact that the semi-nomads or herders are not often outside in the day during summer. For a researcher doing ethnographic fieldwork using qualitative methods, including participant observation, this was not an easy situation in which to start fieldwork and to enter a community, even in a hospitable country like Morocco, where people often invite strangers for tea and invite them into their houses. I did not

5 Since 1980, Imazighen (sing. Amazigh) has come to refer to all Berbers from North Africa. Regional subgroups are distinguished with specific names [18]. Imazighen, in its original meaning, also refers to the Berbers of central and south-east-central Morocco where the author conducted fieldwork. Other Berber subgroups in Morocco are Ishilhayen in south-western Morocco and Irifiyen, the Rifians in north-eastern Morocco [18]. The term Amazigh did not come from scratch in 1980, in fact it has been there for longer than that. Since it is the endonym, it was 'revived' to be used instead of potentially derogatory terms like 'Barbar' in Arabic and 'berbères' in French. 
find it possible to start the research by knocking directly on private doors, and therefore I had to find other ways to gain access to the community. Fortunately, this all changed after a month, when we all acclimatised and our children had started school. This additionally gave us a point of contact with other families. It was very important to stay a whole year in the region, so as to know more about the people and to experience everyday life amongst them; for example, to understand how semi-nomads move from one area to the other and why they choose specific places. In other words, the long stay in the field enriched the author's knowledge of the local transhumance, the day-to-day routine of local Amazigh groups, and the ecosystem and the financial strategies of women in the area. I also developed an eye for institutional designs on access to commons for local people.

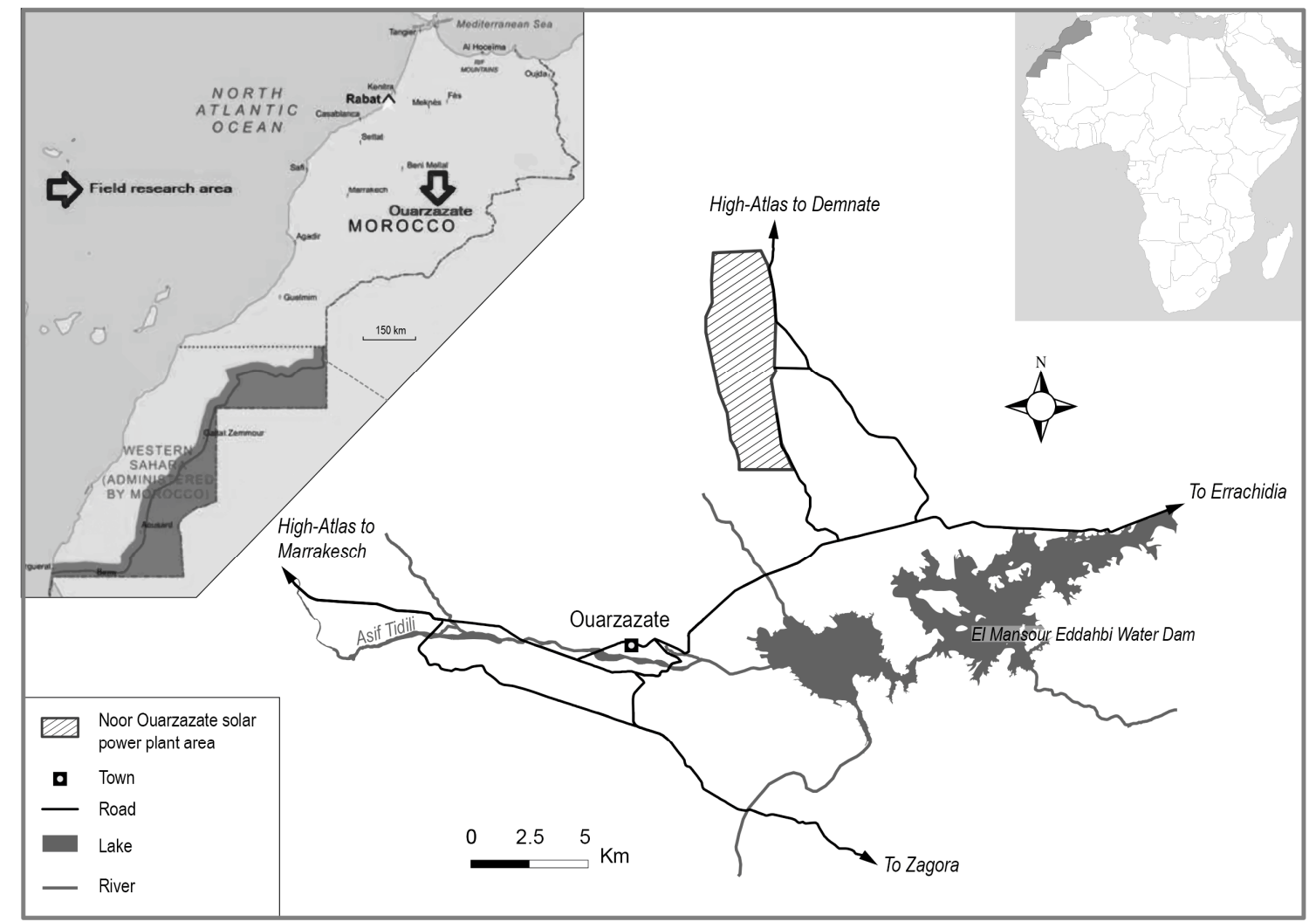

Figure 1. Location and map of the wider case study area. Map compilation and design: Gämperli Krauer Ulla (2018), CDE, Centre for Development and Environment, University of Bern, Switzerland. Geodata source: OSM data by OSMaxx (2018). Geometalab, HSR University of Applied Sciences Rapperswil, Switzerland, and Ryser, Sarah [4], Institute of Social Anthropology, University of Bern, Bern, Switzerland (Parts of the map were used for previous publications).

The study mainly focuses on four main categories of local actors affected by the project. Each of these groups of actors has individual interests in the solar project, which are very varied. All of these groups often consisted of women, or mixed women and men:

(a) Herders, pastoralists, and local community members who used the 3000 ha Noor solar project area (Figures 1 and 2) as a passage for transhumance and collecting herbage, fuelwood, and other plateau products are concerned with the new utilisation of the territory. Even if it is not a desirable location for extending pasture, it is not what is commonly called 'wasteland', which the state understands as land which is not productively used. Following the establishment of the project and the lack of access to the land for transhumance, collecting wood and herbs for animal fodder, and plants for medicinal or domestic use, or the use of the pathways, local community members, who once used the land for this purpose, had to seek alternative options. This group has little 
bargaining power even when they can take part in the decision-making processes. Even a $\mathrm{Na}^{\prime} \mathrm{b}^{6}$ from a village, the communal land representatives aradi aljoumoua, has little bargaining power because they are between their community and the local state representatives. It is, for example, difficult for a $\mathrm{Na}^{\prime} i b$ to refuse such an investment on their own communal land.

(b) Local community members (women and men) from neighbouring villages who do not have access to jobs and receive no related short-term benefits. They will be looking for alternative means of subsistence and a coping strategy, such as involvement in government development programmes (i.e., participation in cooperative, Maroc vert ${ }^{7}$ and ' $\mathrm{INDH}^{8}$ ). Through programmes such as these, the Moroccan government and MASEN argue that the local community members would be able to earn money whilst at the same time be empowered through information, awareness, government support, and easy access to economic and social amenities, including health facilities, education, and the promotion of local 'wares' or products on the market, thereby reducing losses arising from the LSLA project. These affected people, community members from neighbouring villages (in the Atlas Mountain for example), are completely cut off because they are not part of the Ait Ougrour community and therefore not included in decision-making. Community members of neighbouring villages are not included in most of the CSR programme but still affected by the loss of the 'old' commons. In their case, they used the land mostly as passage. Very few CRS projects address this actor group.

(c) The third group of actors comprises the so-called local non-citizens. These are actors who moved to Ouarzazate and the surrounding area, close to the solar project, purposefully in search of new opportunities. Some of these may include, for example, prostitution. The gendered implications of these new arrivals to the local communities also need to be ascertained. What then becomes of these communities in terms of cost and benefits, such as rents and related fees? These actors have almost no bargaining power, and are not concerned at all with accessing the 'new' commons, as they were not affected by the loss of the 'old' commons.

(d) The fourth group comprises Moroccan policymakers, such as the politicians, the royal institutions, especially King Mohammed VI, the very heterogenic local administration, and international actors, such as foreign companies and governments (such as Spain, Germany, France, and China) and foreign state actors, development agencies, NGOs, and technical companies, mainly from Germany, Spain, and Saudi Arabia. These actors had, from the beginning, a level of high bargaining power. Some have made decisions about the implementation of additional CSR projects, and some were able to decide on the price of common land in terms of acquisition. They are also the first to have all the information about various processes and can share this information with whomever they decide. Local state representatives, such as the Caï ${ }^{9}$, the governor of a region, or the president of a community, also have high bargaining power; they can interpret state control according to their understanding of the governmental supervision of a region or a community. Development agencies and NGOs decide to whom a CSR project is important and who has access, and often they are also influential in deciding which CSR projects will be implemented.

6 The $\mathrm{Na}^{\prime} i b$ or $\mathrm{Na}^{\prime} i b a$ (female in very few cases) is the elected person to speak on behalf of the people. For example,

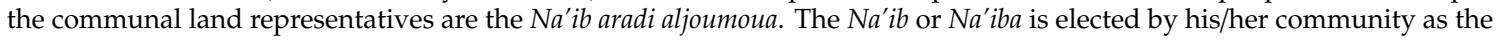
person responsible for managing the collective land affairs and maintaining contact with the state's Directorate of Rural Affairs (DAR). It is any person chosen by villagers to be in charge of any talks or communications with another party, like the inverstors or the state, as well as the case of dividing the land.

7 For more information see footnote 1.

8 National Human Development Initiative (INDH, the French acronym for Initiative Nationale pour le Développement Humain).

9 At the times of French and Spanish colonialization, Caïds (plural of Caïd, which means leader or head of an authority office) were appointed in communes to maintain control. It was a type of indirect ruling office structured of men representing the state. In every district the Caïd/a exercises a great deal of power, keeps the peace, manages people's daily affairs in terms of security, policing and gendarme armed forces, and represents the authority at the communal level. Today the Caïd is the local representative of the Ministry of Interior. 


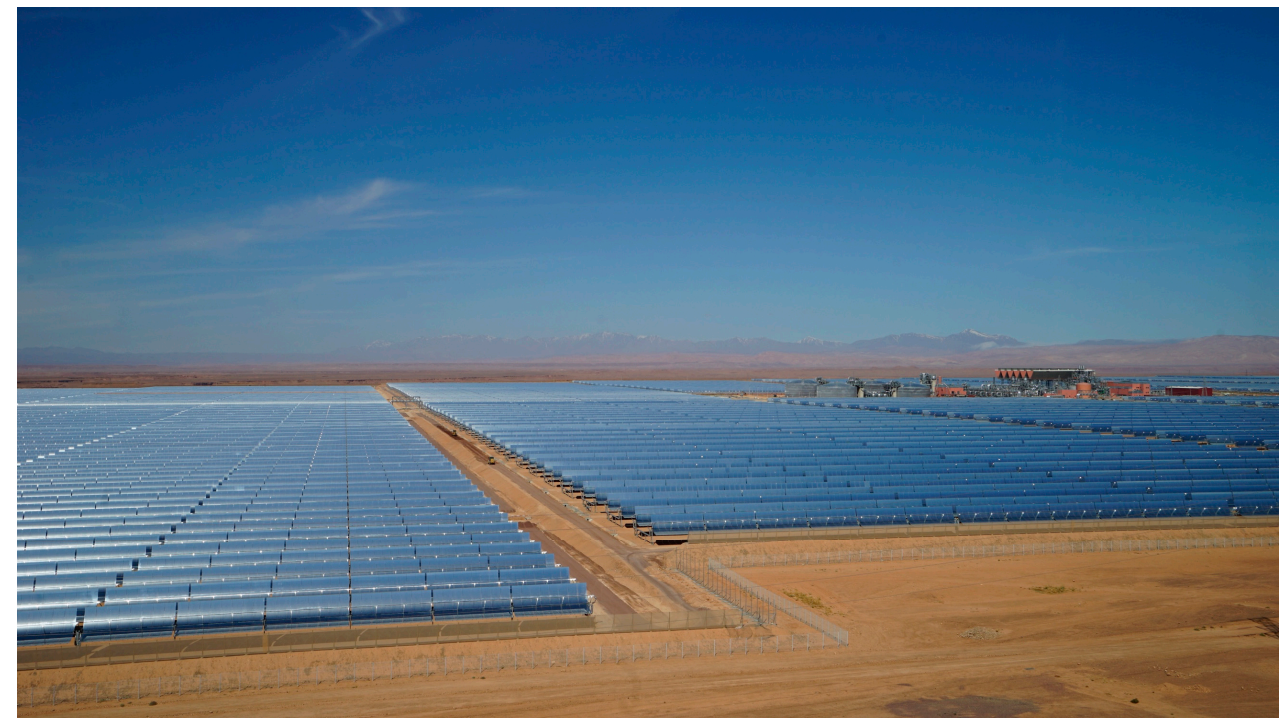

Figure 2. Noor Ouarzazate Solar Project complex (Photo: Sarah Ryser 2018).

\section{LSLA Investment Policies and Creating National and Local Identities through Projects}

In order to understand the anti-politics machine and levels of identity operating in the context of Morocco, one has to understand that the royal institution in Morocco (especially King Mohammed VI) can be considered an arbitrator among the different Moroccan populations. During protectorate times, however, the French created tensions between the Amazigh and 'Arabs' [19], but it seems that the idea of the French using the Amazigh to divide Moroccans into Amazigh and 'Arab' was somewhat distorted (Diary, Fieldnotes Ryser 2015-2018) ${ }^{10}$. The royal family lived in exile during the period of the French protectorate and Spanish colonisation. Local people often referred to Thami Glaoui, who ruled the research area at the time as a dictator. He used his power, gained by cooperating with the colonial power, to oppress the local people (Diary, Fieldnotes Ryser 2015-2018). People interviewed in the research experienced and remember the oppression under Thami Glaoui's rule very well.

Father: Well life at the time was cruel and difficult, starting from $1912 \mathrm{on}$. And if you own a sheep or anything else then it's not yours because the authorities take all what they see. My father used to go to 'Koulfa' (military conscription), he worked for free in Tichka ${ }^{11}$ and other places.

Author: You mean the Muqaddam and Amghar (local authorities) practiced their authority here?

Father: That's true, as I told if they saw anything that belongs to you, they took it. It's not yours anymore.

First son: There was this centre of Telouet, they used to take everything like wood from Imghran to there. They used to take wool, almonds, and anything else. El Glaoui used to rule all of the south-east and Marrakech too as he was the Pacha of Marrakech.

Father: He had sort of three Kasbahs here, one also in Taourirt. If we happen to be four men in a house, then one of us should go to work with him. At that time, there was nothing neither for men nor for women. Things like clothes, shoes were not available as they are now. All there were as shoes was sandal-like partly made of palm tree leaves.

Second son: I think there weren't covers too, people used to sleep on hay to keep warm.

10 The informant is referring Mohamed Mounib [20] statements in his work: to Al-dahîr 'al-barbarî́: akbar ukdûba siyâsiyya fî tarikh al-Maghrib al-mu'asir [The 'Berber Decree': The biggest lie in the history of modern Morocco].

11 Local Mountain chain 
Father: No electricity too, only fire was used as light source, for example when having dinner, one should set fire next to them in order to have a clear sight. And some time after came the candles, lanterns, carbon, and then the gas bottle during 70s and 80s. I was born in the 50s, so all what I know is just from what I was told. El Glaoui used to kill people too, he was very authoritative. There's still one of his prisons in Kasbah Tamddaght where people were tortured and killed. People used to have no rights, either you do what you're told or be killed. (Father and two sons, living in Tasselmante, Morocco, excerpt from an interview conducted in February 2017)

They often mentioned in the interviews how different the rule of Thami Glaoui was from that of King Mohammed V (living at that time in exile) and his grandson, the current King Mohammed VI. The pan-Arabist nationalist Allal al-Fassi and members of the nationalist movement exploited a legal decree issued by the French protectorate power to fuel this idea of division.

The marginalisation and later ban on Tamazight as a language and culture was essentially because of the Moroccan regime's adoption of Arabisation as a programme that pushed nationally under the strong influence of pan-Arabist ideologies coming from the east. Everything therefore related to the Amazigh was by turns either neglected or attacked. The tensions between the Amazigh and people influenced by pan-Arabism ${ }^{12}$ were reconciled by King Hassan II, who also chose an Amazigh from Khénifra for a wife. This move is seen as one of the first steps toward the national unity of the Moroccan people after the French protectorate ended in 1956.

The research between summer 2015 and 2018 showed that the royal family enjoyed a high degree of esteem among the local Amazigh groups, especially after the periods of the protectorate and the era of the unloved Thami Glaoui rule. Despite the impact of the solar project in terms of the loss of communal land, it did not meet much resistance, at least at the beginning, because of local people's love for King Mohammed VI, and maybe also their fear of repression. There certainly was respect for this method of conducting development. This is remarkable, because this form of land alienation took and still takes place in many Amazigh communities as land grabbing by the state and international and national companies on a large scale [3]. Several local people told the researcher this, and tribes and communities deprived of their collective, or even private, lands could be observed during the fieldwork, not only in Ouarzazate, and not only for green energy infrastructure, but also in the whole Draâ valley, the Souss, Haouz and in the eastern part of the country-for example, the province of Figuig. This lack of resistance was not always the case. When King Hassan II, the current King's father, constructed a large dam in the research region in 1970, it was contested until local people realised its utility for irrigation as well as its ability to mitigate group conflicts stemming from water scarcity [4]. The dam issue is particularly important for the solar project, because its water is used for cooling solar installations such as Noor I (although a small amount, it is still significant from a local perspective).

There was no initial resistance to the solar project, however, as King Mohammed VI is admired locally for his social projects. The current King's positive reputation is based on efforts such as (a) fighting poverty, which meant bringing infrastructure and jobs into marginal regions; (b) introducing a new family law (New Moudawana), which was intended to change, at least on paper, women's inheritance rights; and (c) normalising the political situation after King Hassan II, which contributed to local conflicts [21] (and see also, in the context of gender and reconciliation commission after Hassan II, Bettina Dennerlein, [22,23]). The current King also promised that the gains from the solar project would be locally distributed and should also create new jobs for the local population. At the same time, it should make Morocco an energy-independent country and generate surplus green energy for export to other African and European countries. The media announced that up to 90,000 green jobs would be

12 I prefer to use this term and not 'Arab', because there were Amazighophone people too in the nationalist movements and indeed due to ignorance and Arabisation conducted through education, a significant amount of Berber-speaking masses were victims of Middle Eastern pan-Arabist ideologies. 
created in Morocco by 2020 [24]. With this development plan, the Moroccan government endorsed a local infrastructure development policy that they called 'regionalisation', allowing regional autonomy through the devolution of power to regional provinces. This move makes large-scale land acquisition a relevant issue in the politics of regionalisation: this regional investment option came at a time when regional provinces had gained some autonomy over the land. The politics of regionalisation also serve as an anti-politics machine, however, because the process was still controlled by the King, who did not—and still does not-focus exclusively on solar energy and green development.

For the local purpose of gaining a positive reputation, the King's and the government's discourses highlight that the solar project is also linked to local development initiatives that are defined as representing regional development, combining 'traditional' and 'modern' approaches. One element of these discourses is the promotion of traditional handicrafts as a means of keeping local traditional knowledge and creating jobs for women in rural areas. Altogether, these strategies constitute a holistic policy that the Moroccan national government—controlled by the King-uses to promote its vision of rural development. National-level development projects involving large-scale land investments in agriculture and infrastructure are at the top of the political agenda. Such projects include the largest ports in Africa (the 2009 Tanger Med and Tanger Med II) and the national railroad network. The recently opened Moroccan High-Speed Rail (TGV Al Boraq or HSR) network links the port of Tanger Med with other important industrial centres, and guarantees the fast transportation of passengers as well as goods and services. It is the first high-speed line on the African continent (for more and current information see, for example Reference [25]). The line between Tanger and Casablanca was inaugurated on 15th November 2018, and the journey between Tanger and Rabat takes now $1 \mathrm{~h}$ and $20 \mathrm{~min}$ by HSR, instead of $3 \mathrm{~h}$ and $45 \mathrm{~min}$ by normal train [25]. All these investments are legitimised by the argument that they are boosting the nation's green development and providing new job opportunities on all levels, with a particular focus on women and on mitigating climate change.

\section{1. 'Moroccan Green Energy Projects' as Part of the National Climate Mitigation Discourse}

Discourses on national strategies to support women and protect the environment are based on visions of national unity related to territory and land. The Kingdom of Morocco covers 710,800 km² and has a population of 35 million people, most of whom inhabit the northern and central part of the country. Yasmine Berriane [26] describes in her article, entitled The Complexities of Inclusive Participatory Governance: The Case of Moroccan Associational Life in the Context of the INDH, how Morocco transitioned "from an authoritarian regime to a democratic one" after forty years of rule by King Hassan II (1961-1999), at least in the official discourse about the transition process (see also Reference [27]). Berriane [26] illustrates in her article how, in Morocco, democratic norms and practices (such as the promotion of inclusionary practices of participation) have been combined with practices associated with authoritarian regimes, leading to a hybrid political system. She shows through this the ambivalences of current political change in Morocco. The French protectorate ended in 1956, when the French recognised the Kingdom as independent. Spanish colonial power ended only after the marche verte in 1975. Some 350,000 unarmed Moroccan civilians entered the Western Sahara/Moroccan Sahara (depending on the political point of view) in November 1975. Morocco extended its control into the two provinces of Oued Eddahab and Aousserd, where it faced a separatist movement, Polisario, which is nowadays based in Tindouf in the Algerian Desert. From the official national point of view, Morocco recuperated its land after Spanish colonisation and did not occupy the Saharan regions. Much historical literature, which will not be referred to further in this article (for further reading see Reference [21]), supports the official Moroccan position. This Western Sahara conflict is important in an indirect way for the research in Ouarzazate (although as the region is in the Draâ-Tafilalt, it is not part of the Moroccan Sahara) because the conflict there led to a strong unity in the nationwide discourse, and acts as a symbol of Moroccan unity and political stability. The conflict in the Western, or Moroccan, Sahara increased "the King's legitimacy as defender of the country's territorial integrity" [28] (p. 51). 
Based on this history, the issue of national unity-one of the main red lines of the regime-is seen as focused on the throne and the Royal Family, and therefore their opinions are very important in informing views of the Moroccan public, as the author's data have shown. The Western Sahara conflict is used as part of the justification for accelerating the implementation of the decentralisation in Moroccan regions [28]. The Moroccan decentralisation process, which started with independence from France, is important for this research and the research area, regarding the implementation of local autonomy.

The solar energy project in Ouarzazate needs to be understood in this context, as it reinforces the hegemonic concept of the issue of national unity and the discourse on fighting together against climate change and global warming. State projects such as that under study can count on wide support within Moroccan society. These discourses are further linked to other issues with positive connotations ${ }^{13}$, such as gender equality, participation, and decentralisation, which were rhetorically also used by King Mohammed VI to underline the process of modern technological and societal transition, albeit in the context of tradition, as mentioned above (see also Reference [26,29]). This discourse does not match reality, however, as there is a huge difference between the governmental discourse and its presence in the media on the one hand, and the daily experiences of livelihood challenges in rural Moroccan areas on the other. The whole process of investing in collective land is framed within broader key words, such as development, gender equality, and human development. This is a way to justify these big extensive projects and also to justify the use of collective lands (see Reference [29]). There is a small example of where to find the controversial reality between political discourse and daily life. A couple of years ago the Moroccan government stopped the use of plastic bags, in accordance with the COP $22^{14}$ in Marrakech in 2017. Many people disapproved of this action, even though it was under the umbrella of protecting the environment, as the state had not provided alternatives to such bags and the black market for selling plastic bags in Morocco was growing year-by-year. The project was named 'zero mika'15, and was accompanied by a national campaign regarding the negative impact of plastic bags on the environment. Why does the government not similarly encourage and help locals to sell pots made of palm fronds or reeds, a material that is not only $100 \%$ biodegradable but also a traditional handcraft with locally abundant materials? Cloth bags are now available everywhere in Morocco. Many shops use paper bags, but most of the cloth bags are produced by an external company and not by local actors. This means that the 'zero mika' project enables only a few people to profit from the new income source, thus supporting the growing black market. There are local people working on traditional handcrafts and making baskets and pots from reeds or palm fronds, as the following citation will show. Therefore, the project 'zero mika' should support these local producers as well.

"Tasselmante has a few men working on traditional handcrafts like making pots from palm fronds and knitting woollen garments with sheep's wool, or the carpentry and engraving of wooden doors with Tifinagh. Many of those guys who worked on traditional handcrafts have died. Some men are working as carpenters. Near the water dam you can also find men working with palm fronds or reeds, making all kinds of pots, chairs, sunshades, or camouflage for the garden". (Younes, male ca. 22 years old, living in a village close to the Solar Project Ouarzazate, Morocco, excerpt from an interview conducted in October 2018)

Gender is also important in this context as a dimension of social actions that defines the tasks and roles (with considerable variation) that people play in several spheres of life, but it is also an arena of overlapping interests. Here again, the topic of contradiction and ambiguity returns.

13 Positive within a specific global and national context of international norms, national discourse of change, development, human rights and so on. These terms are not per se positive but they are seen as positive within a more general frame or context.

142016 United Nations Climate Change Conference.

15 Mika is Darija for plastic bag. 
"We did receive farm animals from MASEN (Moroccan Agency for Sustainable Energy) and we received two sheep from 'Rosa' three years ago. More recently, they came to register those who will receive farm animals; they registered 24 names, all men, except me the 25th, who is a woman. They wondered why 24 men and only one woman (laugh). I told them I had to register my name because my husband is working and I'm 'the man of the house' now ... ". (Fatima, female ca. 55 years old, living in a village close to the Solar Project Ouarzazate, Morocco, excerpt from an interview conducted in April 2016)

We should realise that gender-specific roles are limited and flexible, and cannot be identified when individuals, men and women, take or would like to take on 'other' roles that are classified as gender-specific by the CSR projects-which then deprives some men and women of profiting from several CSR projects. The CSR projects do not consider the context of variability and the meanings of gendered roles, because of the loss of an emic perspective. Most of the CSR projects for men from MASEN focus on job opportunities in the solar project, which generate income, while those for rural women do not. Why is this the case? Women should also be able to generate income. Another example is that handicraft projects are not focused on men, even though men work with handicrafts, such as palm fronds and reed pots from the Ouarzazate region, that are sold and generate income. What is the relevance of a large-scale green energy project to environmental discourse and the everyday experience of local people? It would appear that the country's engagement in promoting the discourse of green energy and green economy has instigated a new common feeling. The discourse promoted by the state presenting an African nation with this immense national green energy project and the satisfaction of having a leadership position as the first African nation in solar energy production at an international level is stimulating a sense of community among Moroccans. This discourse includes all Moroccans, the whole heterogenic population of the North African country. The Moroccan government stresses that all Moroccans are part of this sustainable development programme and these discourses are even more visible in the rural parts of the country. As national government actors often claim, based on my fieldwork experiences following official speeches and (conference) press releases, "it does not matter where you come from, what language you speak, what profession you exercise, whether you are male or female-all Moroccans, the whole nation, are included and will profit from this green energy from all different levels". There is an understanding that, "natural common-pool resources disappear for a particular group of people, but 'new commons' like this solar project emerge for the benefit of our entire heterogeneous country". This hegemonic discourse makes it difficult but not impossible for the actors in this research, including those working for the solar project, to take a critical attitude, to have critical thoughts or to express a critical position in public. This unity not only entails a national political stability, but, due to its location, peace in the country ensures stability. The strategic position of Morocco thus makes it unique in the MENA (Middle East and North Africa) region, because it is able to maintain unity among its diverse religious denominations within Islam and others, such as Judaism, Christianity, and Buddhism, and this unity has been due to the country's ability to transform its political structure compared to the other MENA countries. The capacity for reform was part of the policy efforts that were initiated by King Hassan II in the 1990s and continued by his son Mohammed VI [30] (p. 282). The change of status quo maintained a political system where the kingdom could co-evolve with democratic governance. This strategic move by the kingship and its acceptance of democratic governance makes Morocco a favourite of international and national firms for large-scale investments.

Infrastructure projects are also legitimised by the argument that they reduce the country's dependency on foreign supplies to meet its growing energy demands [31] (p. 291). It is argued that the specific geographical location of Morocco makes it very suitable for producing solar, wind, and water energy, and Morocco is also the only African country with a power transmission cable link to Europe [31] (p. 291). Several international banks are involved, as well as development agencies and technical companies from Spain, Germany, Saudi Arabia, and China. These investments are made according to the King's decision and vision for Morocco. At the national level, King Mohammed VI and 
the government demonstrate a strong intention to realise these ambitious renewable energy projects. There are also plans to use green energy for water desalination rather than irrigation systems and to serve inhabitants, as part of the Moroccan energy policies. The projects involving energy production and water desalination are linked to agricultural development programmes.

\subsection{A Regionally Green Morocco with Modern Agrarian Development}

In public discussions about the subject, the King and politicians underline the importance of these projects for all Moroccans. Their discourse aims to stimulate a sense of community among Moroccans.

Dear people,

We are determined to maintain our course in order to complete the constitutional institutions and meet the requirements of good governance. The will that invigorates us in this respect is matched only by our determination to persevere to give substance to our societal project combining economic growth, sustainable development, and social solidarity [. . .] It is in the same spirit as the desire to endow Morocco with the capacity to produce renewable energies, thus helping to give concrete manifestation to our vision of sustainable development. Hence the implementation of the solar energy program, especially the launch of construction sites of the 'Noor Complex' in Ouarzazate, in parallel with the deadlines included in the wind energy program. Besides their environmental importance, these projects will make us less dependent on energy imports. It is therefore necessary to engage in an efficient training policy and to develop skills in this domain, which on top of that will favour the implementation of the National Charter for Environment [ . . .] 'Green Morocco' Plan contributes to the modernisation of the agricultural sector, taking due account of the constant interest of small farmers in improving their living conditions ${ }^{\prime 16}$.

It is thus clear that the project is related to the vision of a "Green Morocco" and the protection of the environment. These discourses add much credibility to investment and the impact this has seems to be minor when labelled this way. Indeed, governmental development programmes, such as le Programme Maroc Vert elaborate a tailored agricultural strategy for each of Morocco's agro-ecological regions and include as one of their key goals the mobilisation of 700,000 ha of collectively owned land, to be used to connect small-scale farmers to the national (and global) market, including the use and promotion of sustainable energy [33,34], as well as that of gender-supportive policies.

Under these projects, small-scale farmers receive double governmental support. This is important for the case study because women are active in smallholder agriculture and so, through these programmes, the Moroccan state argues that it serves multiple purposes: a political objective that combines agriculture development, women's empowerment, and the use of green energy through the installation of solar panels, for example, on farmers' roofs, which is financed with government money. It is argued that

\footnotetext{
16 Cher peuple,
}

Nous avons la ferme volonté de maintenir le cap pour parachever les institutions constitutionnelles et répondre aux impératifs de bonne gouvernance. La volonté qui Nous anime à cet égard n'a d'égale que Notre détermination à persévérer pour donner corps à Notre projet sociétal alliant croissance économique pérenne, développement durable et solidarité sociale ... ' '... C'est dans le même esprit que s'inscrit la volonté de doter le Maroc de la capacité de produire des énergies renouvelables, contribuant ainsi à donner son expression concrète à Notre vision du développement durable. D'où la mise en oeuvre du programme d'énergie solaire, notamment le lancement de chantiers de construction du 'Complexe Nour' à Ouarzazate, parallèlement aux échéances inscrites au programme d'énergie éolienne. Outre leur importance environnementale, ces chantiers nous rendront moins dépendants des importations énergétiques. Il est donc nécessaire d'engager une politique de formation efficiente et de développer les compétences en la matière, ce qui favorisera, de surcroît, la mise en oeuvre de la Charte nationale de l'environnement ... ' '. . . Le programme 'Maroc Vert' contribue à la modernisation du secteur agricole, en tenant dûment compte de l'intérêt constant qui doit être porté aux petits agriculteurs, en vue d'améliorer leurs conditions de vie... '30/07/2013-Texte intégral du discours adressé par SM le Roi à la Nation à l'occasion de la Fête du Trône-Casablanca. [32] 
support for smallholder farmers will reduce outmigration from rural to urban areas and is used to legitimise the acquisition of land for solar energy by connecting the benefits of the solar project to the modernisation of rural agriculture.

The implementation of the solar project has also been linked to the discourse on agriculture development, by indicating that community members who have lost access to land and its related common-pool resources will be incorporated into such modernised agriculture projects. While women are active in small-scale agriculture through these programmes, which the Moroccan state argues serve multiple purposes, the political objective thus combines (a) agriculture development; (b) women's empowerment; and (c) the use of green energy through the installation of solar panels, for example on farmers' roofs, which is financed with government funding. Therefore, in addition to the argument that support for small-scale farmers will reduce outmigration, it is also argued that it will legitimise the privatisation of the previous common land for solar energy based on the ideology of modernity and the discourse on gender-sensitive rural development as benefits of the solar project as part of the modernisation of rural agriculture. The Maroc Vert programme (PMV), the Morocco Green Plan, launched in 2008, is expected to be one of the "the main engine[s] of growth" [28] (p. 21) and should affect poverty reduction in the whole country [28] (p. 21). According to Bergh, this national development programme aims to stimulate "the involvement of citizens and of associations" with rural and urban development and provide support in the sector of agriculture, including small-scale farmers [28] (p. 21).

For the so-called 'autochthonous groups', gender relations are based on Islamic norms but nevertheless give women in the local context the opportunity to participate in the new initiatives, especially in female cooperatives ${ }^{17}$. Since 2005 the INDH, Initiative Nationale pour le Développement Humain, has governed and financed several projects, especially for women but also for men in Morocco, and been promoted as the "key development strategy for the country, with important implications for local-governance arrangements" [28] (p. 21). The INDH 'n'est ni un projet ponctuel, ni un programme conjoncturel de circonstance, c'est un chantier de règne' (The speech by King Mohammed VI, 18 May 2015). The so-called 'cooperatives' are often included and subsidised by the INDH, which proclaims that its

17 'Appeared in the luggage of French settlers, cooperatives were first put at their service before the dahir of 8 June 1938 allowed the establishment of cooperatives among artisans and Moroccan farmers. But it is truly in the aftermath of independence that these economic entities will find an echo in the state. Cooperation is indeed recommended, both by state leaders and by various political and trade union organizations... ' [35].

'Through their values of democracy, solidarity, sharing and mutual aid, cooperatives play an increasingly important role in the economic and social development of Morocco. Their attractiveness has increased especially since 2005, when the launch of l'initiative nationale du développement humain (INDH), the National Initiative for Human Development, encouraged the creation and sustainability of social and solidarity economy structures. This contribution addresses the issues of cooperative entrepreneurship, examines the institutional and fiscal support offered by the Moroccan state to cooperatives and finally presents the economic and social weight of cooperatives in the Moroccan economy ...'

'... An even more notable asset is that these cooperatives are $95 \%$ female. In fact, female entrepreneurship in cooperatives is an important turning point in Moroccan society, allowing women to have financial autonomy and more power in decision-making ...' [36].'

Apparues dans les bagages des colons français, les coopératives ont tout d'abord été mises à leur service avant que le dahir du 8 Juin 1938 n'autorise la constitution de coopératives entre artisans et agriculteurs marocains. Mais c'est véritablement au lendemain de l'Indépendance que ces entités économiques vont trouver écho auprès de l'Etat. La coopération est en effet alors préconisée, tant par les dirigeants de l'Etat que par différentes organisations politiques et syndicales ... ' [35]. 'A travers leurs valeurs de démocratie, de solidarité, de partage et d'entraide, les coopératives jouent un rôle de plus en plus important dans le développement économique et social du Maroc. Leur attractivité croît surtout depuis 2005, année du lancement de l'Initiative nationale du développement humain (INDH) encourageant la création et la pérennisation des structures de l'économie sociale et solidaire. La présente contribution traite des enjeux de l'entrepreneuriat coopératif, examine les appuis institutionnel et fiscal offerts par l'Etat marocain aux coopératives et présente enfin le poids économique et social des coopératives dans l'économie marocaine ...'

'... Une place d'autant plus notable que ces coopératives sont à 95\% féminines. En fait, l'entrepreneuriat féminin en coopératives constitue un tournant important dans la société marocaine, permettant aux femmes d'avoir l'autonomie financière et plus de pouvoir dans la prise de décision ... ' [36]. 
programmes "fight against poverty ${ }^{18}$, precariousness"19 and "territorial scaling-up" ${ }^{20}$. It should be, as Bergh mentions, a "participatory mechanism of dialogue and consultation (concertation)" which "[is] put in place by the (newly established) Regional Councils and the Councils of the other local authorities to stimulate the involvement of citizens and associations in the formulation and follow-up of development programmes" [28] (p. 21).

As mentioned by Berriane [26], several micro-projects by local representatives of the state are elaborated, financed, and implemented throughout the INDH. These representatives work in close collaboration with the INDH to build on a pyramid structure consisting of elected council members and NGO leaders. NGO leaders should represent the inhabitants' interests when designing the first phase of a project [26] (p. 93). Often, local authorities (mainly representatives of the municipal district or of the Prefecture, led by a governor designated by the King) help in the first phase of project development. In the second phase of the project development, local committees, including elected members of the municipal or communal councils (conseils communaux), local representatives of the state, and NGO leaders, select a first set of projects to be supported by the INDH. After these two phases, the selection process comes under the supervision of regional councils and the central committee [26] (p. 94). At the top of the pyramid (Figure 3) are the prefectural committees (comités préfectoraux) led by the governor, along with civil society representatives (a third of the members of this committee).

At the top of the pyramid is also the Prime Minister, however, who controls the whole process [26] (p. 94). Obviously, the King has the opportunity to intervene in any phase of the implementation process. At least $12 \mathrm{INDH}$ projects have been set up in the region of Ouarzazate, including, for example, a 'centre de formation des femmes rurales à Ghessate'. In the current state of research, these projects must also be understood as governmental compensatory measures for the local population, in two senses. First, during colonisation, rural regions in Morocco were often marginalised, and today the Moroccan government wants to improve the infrastructure in these areas. Secondly, it is compensation for LSLA in order to cover current needs and to determine the priorities for development projects. It therefore seems to be more than a sustenance strategy for the inhabitants of the region (see Reference [37] and current research). The state strategy of marginalising certain regions in Morocco during protectorate and post-protectorate eras had "drastic economic effects on the rural areas" [19] (p. 148), mainly on the Amazigh population, and migration for unemployed young people to bigger cities was the only option left for (poor) rural Amazigh [19].

18 Support for access to social services, infrastructure and basic sanitary and educational, cultural and sports facilities. Social, sports and cultural animation. Training and communication actions. Income Generating Activities and micro projects generating jobs and stable income [32].

Soutien à l'accès aux services sociaux, infrastructures et équipements sanitaires et éducatifs de base, culturel et sportif. Animation sociale, sportive et culturelle. Actions de formation et de communication. Activités Génératrices de Revenus et microprojets générateurs d'emplois et de revenus stables [32].

19 The upgrade of the reception centers. The creation (if necessary) of specialised reception centers by target category. Family, economic and socio-professional integration. Support to associations fighting against precariousness. Support for people in vulnerable situations [32].

La mise à niveau des centres d'accueil. La création (en cas de besoin) des centres d'accueil spécialisés par catégorie cible. L'insertion familiale, économique et socioprofessionnelle. L'appui aux associations œuvrant dans la lutte contre la précarité. L'accompagnement des personnes en situation de vulnérabilité [32].

20 Health support. Rural electrification. Potable water. Roads and rural tracks. Educational support [32]. Appui à la santé. Électrification rurale. Eau potable. Routes et pistes rurales. Appui à l'éducation [32]. 


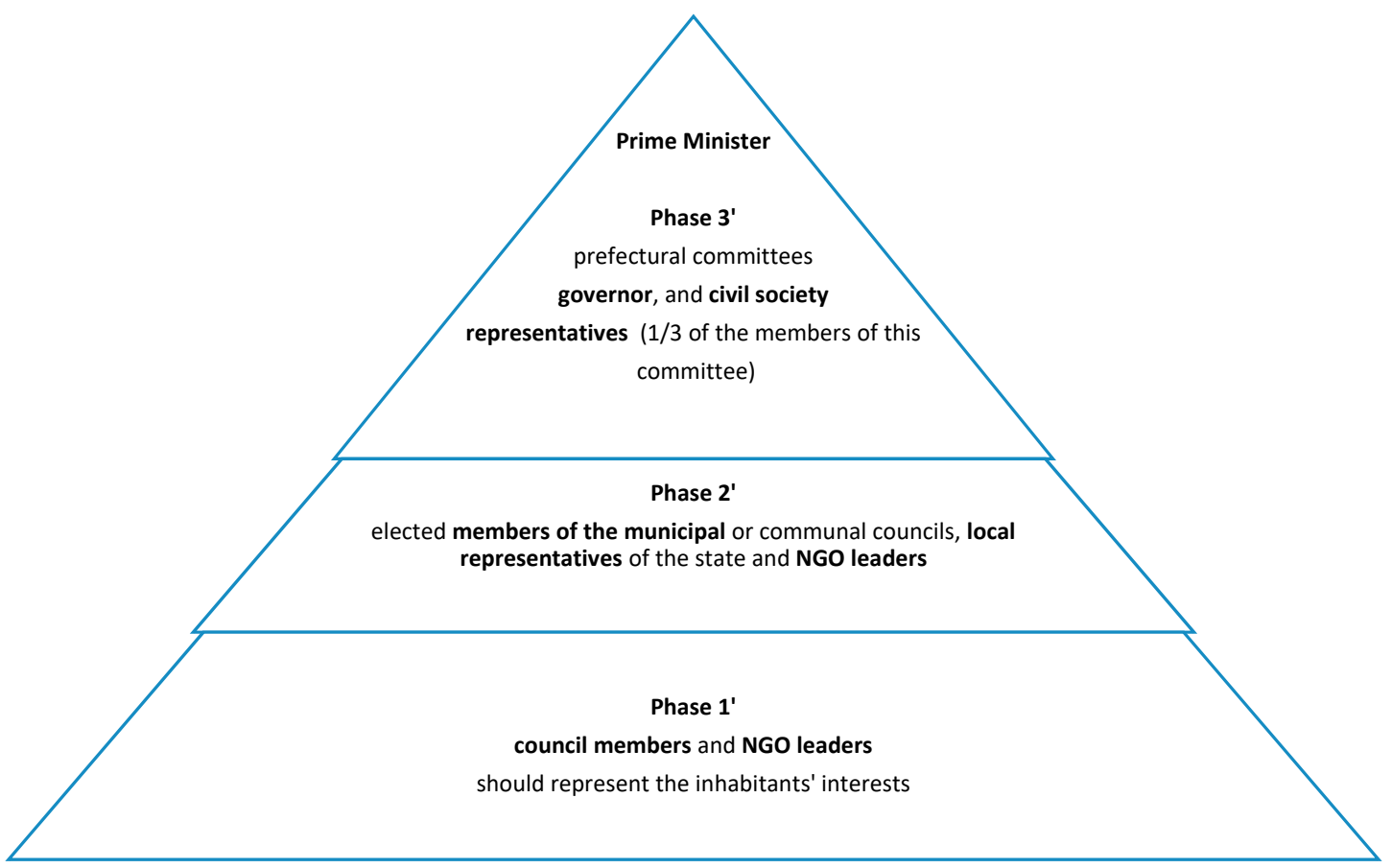

Figure 3. INDH development phases of the project implementation processes.

4.3. Discourse on Ethnic Identity and Amazigh Heroism as a Strategy Against Opposition and Objection and Beyond Rhetoric: Gendered Initiatives for Women's Empowerment at Local Levels

The government has also been very strategic in ensuring little resistance from the local people, by using historical accounts in political discourses to discourage opposition to the solar project in the area, and to gain support from the dominant Amazigh community to which the land belonged. For instance, in political discourse in favour of the solar project, officials refer to so-called 'worthless land' (terre inutile) becoming 'valuable land' (terre utile) (see, for example, Reference [38]. This distinction between inutile and utile was used by the protectoral power to distinguish between dominated land and non-dominated land, which structured the space for access to economic development during the protectorate era (see, for example, Reference $[3,38]$. The distinction between 'valuable' and 'worthless' was also used to describe the local people's resistance to colonial control during the French protectorate and the Spanish colonisation period, and represented a sense of pride in the local people, because most of the 'worthless land' could not be dominated entirely during that era. Often, it was the Amazigh population who acted against the colonial domination of European countries. As such, the officials' use of such rhetoric in their political discourses was strategically motivated to show that they represent the interest of the Amazigh population, and to give them the feeling of a common state and to show that the conversion of the land into solar fields is for the common good, of which the Amazigh are part. In 2001, King Mohammed VI made his first speech, reiterating the necessity of teaching the Tamazight language in Moroccan schools [19]. In addition to rhetoric, the Moroccan government has also taken concrete symbolic measures to show commitment to such discourses through several gestures, such as making Tamazight an official language in 2011 and teaching Tamazight in several Moroccan schools, as recognised at the national level. The Royal Institute for Amazigh Culture, L'Institut Royal de la Culture Amazigh (IRCAM), was built in Rabat and the Moroccan researcher Fatima Sadiqi and eight other women were appointed by the King to be part of its Administrative Board.

Legitimisation of the solar project has also been enhanced through the connection of compensation resources to support for the so-called 'autochthonous groups', where women in local communities are given the opportunity to participate in the new initiatives, especially in female cooperatives. Since 2005, the INDH has governed and financed several projects, especially for women but also for men. In the region of Ouarzazate, at least 12 INDH projects have been set up. One of them, in Ghessate, 
is a 'centre de formation des femmes rurales à Ghessate'. This centre will include an educational establishment for professional education (for example, carpet weaving), literacy, nursery education, and sanitation education, linked to gender-beneficial outcomes of the solar project. Small-scale farmers receive double governmental support.

"If you think that the desert is empty, you do not know how to look at it"21

This proverb disrupts the picture of 'wasteland' — there cannot be wasteland, at least from an emic perspective. Only after several months the author learned to detect things like different plants, different types of housing, insects, and other animals in her research area. She also came to realise, pertinent to the Amazigh proverb, that her emic vision changed, i.e., she learned how to look at the desert, the semi-arid and arid areas. After long individual and focus group discussions, visiting many local people in several villages but also speaking with semi-nomads and herders, picking all kind of plants ${ }^{22}$, the author learned how people were affected by the implementation of the solar project. She also realised that several things were not immediately visible or able to be perceived initially. The region was far more than a barren landscape; for example, the author discovered the reciprocal use rights between some herders from the neighbouring community from Azilal and the Ait Ougrour community (Figure 4, see also Reference [4]).

The Azilal people, from the mountain, they come here. But they don't face the same problem as we do. Because it's us who settled here and benefit more from the land. They do have a problem too because they used to go to Tifernin and then to Souss, now they have to go in a truck, they don't have a way anymore, it's blocked now. (Herder, Tasselmante, Morocco, excerpt from an interview conducted in April 2016)

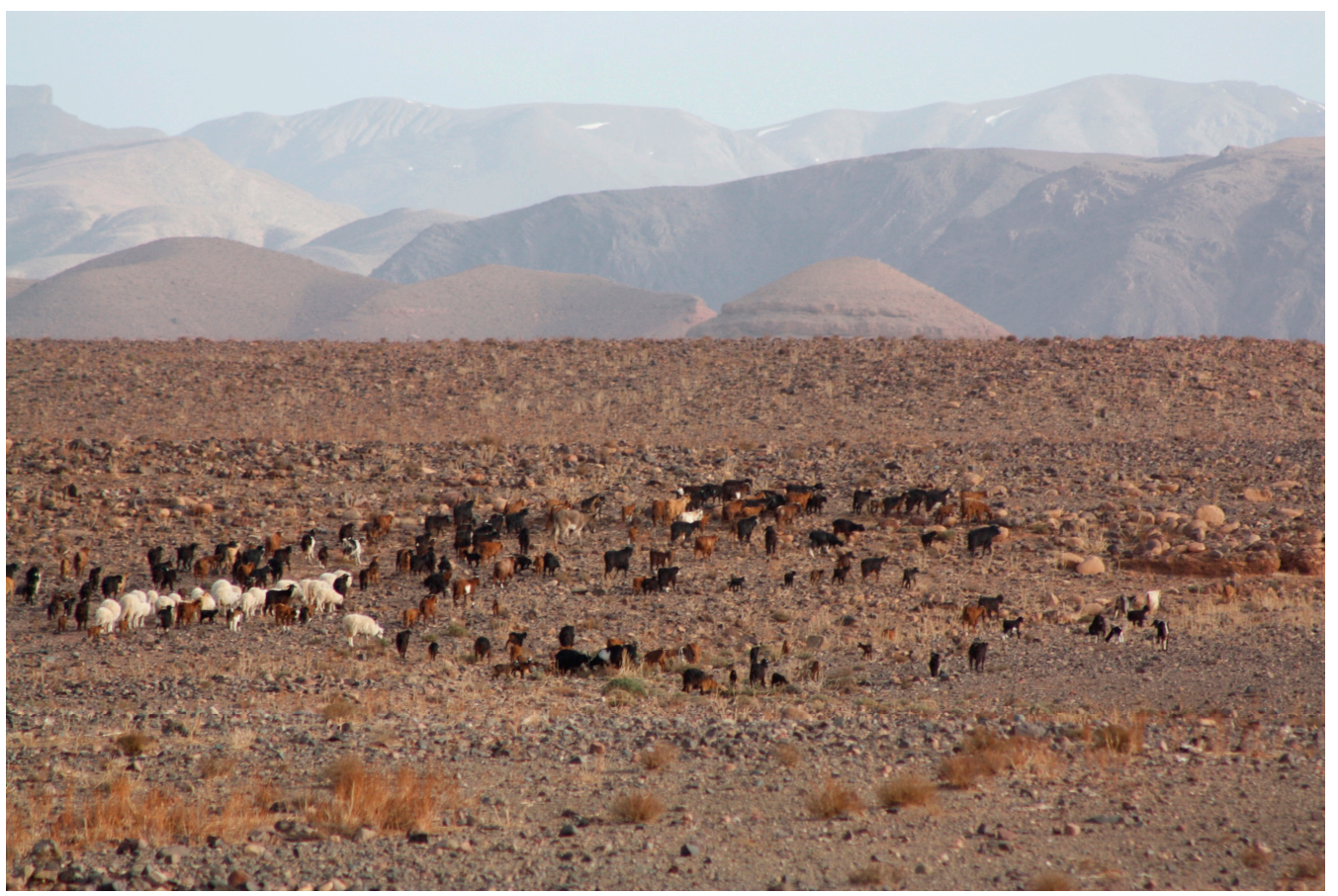

Figure 4. Herders and semi-nomadic groups from the Atlas Mountains with goats and sheep using the area on a reciprocal basis under Amazigh institutions. (Photo: Sarah Ryser 2017). 


\section{Discussion}

The Moroccan state and investors argue that the abundant 'wasteland' is used for modernisation and the production of green energy, and new job opportunities are created in rural areas. Using a discourse with its seeds in the French protectorate, and dividing land into 'valuable/utile' and 'worthless/inutile' parts (see, for example, Reference [38], Moroccan green energy projects, in this specific case, (a) make the worthless/inutile parts of the country valuable/utile; (b) turn Morocco into a greener country-in helping the world fight against climate change; and (c) bring development to rural women and men. This is a 'win-win-win' situation in favour of the solar project. Since 'worthless land' has becoming 'valuable land', and there are now many different types of local people as well others from the 'valuable' parts of Morocco, such as Marrakech, Casablanca, Rabat (Oujda) who come to this area to try and make money. Managers, engineers, and NGOs are coming into 'worthless regions' to work on solar projects or other CSR projects. Using the same example of 'valuable' and 'worthless' land, people coming from valuable regions make the land in the surrounding area of Ouarzazate 'valuable' in a way, however, most of these people with a high position or with work experience use this discourse for their own purposes. Again, these people have access to these advantages, and in a disproportionate manner compared to local citizens. Additionally, locals express mistrust about NGOs and how the money from the land sale has been used.

It was said that an international association (she is referring to an international NGO) was given 3 million dirhams! It's absolute nonsense. We know that they're stealing the money. Now they say the money is no longer available. (Chama, female, Tasselmante, Morocco, excerpt from interview conducted in March 2017 [4])

Informal discussions and interviews during the fieldwork for this case study confirmed what Bergh [39] had already mentioned - that there is mistrust about NGOs and associated work in Morocco because some people get rich at other people's expense by collaborating or participating with NGOs or associations.

In Morocco, the notion of association in the modern sense was introduced by a royal decree (dahir) in 1941. It allowed only the French settlers to create associations and prohibited Moroccans from doing so. Only the Law on Public Liberties of 1958 (which was, in turn, largely inspired by the French law on associations of 1901) accorded the right to associate to everyone. [39]

After the pan-Arabist Allal al-Fassi's nationalist movement, many members of the leftist political opposition found refuge in associations. The law on public liberties was issued in 1958, after the French protectorate, and since then the parliament has adjusted this legislation and applied it to NGOs twice: first in 1973 and, after intense lobbying by civil society, in 2002 (see Reference [26,39]). The 1973 decree gave significant power to some authorities to sanction and dissolve associations, and the 2002 decree "strikes a balance between an opening up toward civil society and the maintenance of 'soft' state control" [39] (p. 47; and see Reference [26,40]). Now it is easier for an association to be considered legal, and the law introduced some additional bureaucratic control measures. These measures give a substantial role, including more power, to some local authority representatives, NGOs, and associations through the 'soft' state control [39]. In the area the author researched, this was particularly true for local 
authority representatives like the Caiid ${ }^{23}$ or the Moqaddam ${ }^{24}$, but also for (international) NGOs, see the quote above by Chama. These negative experiences were very much highlighted in the interviews. Locals mentioned that a group of young people asked the DAR for financing for their own project to found an association. The DAR and the Caïd are responsible for managing the money for the fund. The young people told me that the Caiid refused to grant them permission. While the fieldwork did find that DAR argues that it organises meetings to review local needs, this did not happen often and the demands of the local people had not been considered during these sessions, according to local views. DAR administrators seemed to prioritise the development of projects which they believed would profit local people, however, the locals do not feel included, rather, they think that development decisions are imposed upon them. There is no transparency regarding the use of money and there are no direct cash payments; people are told to make official requests, to which there is either no response at all or none in a timely fashion ${ }^{25}$.

A group of young people had the idea to ask for the financing for a project of our own. But they (the DAR), along with the Caïd (the local state authority) are the ones responsible for the money. We wanted to fund an association with the money but the Caild refused to grant us permission. We have the right to be the ones responsible for the fund, but they refused. (Addi, male ca. 24 years old, living in a village close to the Solar Project Ouarzazate, Morocco, excerpt from an interview conducted in March 2017)

The statement indicates that locals perceive a combination of disinterest from DAR and MASEN in involving them. It also discloses local power relations with elites, such as among village-level state authorities, who seem to control the fund and do not favour the local and bottom-up management of local people. The discourse of having ideas and wanting to set up their own projects indicates a will to have local control over the funds and projects. It also shows a desire for responsibility to be held not by state administrators but by local actors, a desire refused by the more powerful. This has led to the feeling of being unable to get involved and generate development ideas, even though this was the initial goal of the money raised from the sales.

23 'After independence in 1956, Morocco set up a territorial administration in the form of local authorities, both urban and rural. The tribes and the segments that compose them are part of territorial administrations (deconcentrated administration) and local authorities (decentralized administration). Deconcentrated administration organises the tribal space in Caïdats. Each Caïdat is administered by a local authority agent, the Caïd, who is supervised by a Super-Caïd, who, in turn, reports directly to the governor. The Caïdat is divided into Mashiakhat, at the head of which is a Cheikh. The Mashiakhat are subdivided into Douars. Each Cheikh has a Moqadmiin under his command, and each Moqaddam is in charge of one or more Douars. Cheikhs and Moqadmiin are chosen from the population to which they belong. This organisation of deconcentrated administration (Caïds, Cheikhs, Moqadmiin) is part of a tribal tradition that the state has taken over by functionalising these agents and, especially, by detaching the institution of the Caïd from its tribal roots. Unlike the Cheikh and the Mogaddam, who are 'locals', the Caïd is an agent of the state with no ties to the tribe. One could say the institution of the Caïd has been detribalised. Decentralised administration divides the tribal territory into rural communes and electoral districts. It is in this context that representatives are elected, first at the municipal level then at the parliamentary level' [41] (own translation in English from original text below).

'À l'Indépendance, en 1956, le Maroc a mis en place une administration territoriale, et ce sous la forme de collectivités territoriales locales, urbaines et rurales. Les tribus et les segments qui les composent s'inscrivent dans des administrations territoriales (administration déconcentrée) et dans des collectivités territoriales communales (administration décentralisée). L'administration déconcentrée organise l'espace tribal en caïdats. Chaque caïdat est administré par un agent d'autorité local, le caïd, que supervise un super-caïd, qui, à son tour, rend directement compte au gouverneur. Le caïdat est divisé en mashiakhat, à la tête desquelles se trouve un cheikh. La mashiakhat est subdivisée en douars. Chaque cheikh a sous ses ordres des muqadmin, et chaque muqaddam a en charge un ou plusieurs douars. Les cheikhs et les muqadmin sont choisis au sein de la population dont ils sont issus. Cette organisation de l'administration déconcentrée (caïds, cheikhs, muqaddam) relève d'une tradition tribale que l'État a reprise à son compte en fonctionnarisant ces agents et, surtout, en coupant l'institution du caïd de ses racines tribales. Contrairement au cheikh et au muqaddam, qui sont des " gens du cru », le caïd est un agent de l'État sans lien aucun avec la tribu. L'institution du caïd est, pourrait-on dire, détribalisée. L'administration décentralisée découpe le territoire tribal en communes rurales et en circonscriptions électorales. C'est dans ce cadre que sont élus les représentants, au niveau communal d'abord, puis au niveau parlementaire' [41].

24 The Moqqadem is the local representative of the Ministry of the Interior. He acts in the village as an interface between citizens and the Ministry of the Interior, as well as keeping an eye on everyday life in the neighbourhood [sig]' [26] (p. 100).

25 Local community members in Tasselmante and Tiflit. Interviews conducted between September 2015 and May 2017. 


\section{Conclusions}

For all these reasons, large-scale land acquisition processes accompanied by rural development programmes and women's empowerment, in the case of generating renewable energy, must be analysed regarding their implications for critical understanding. The Moroccan case is framed by a 'win-win-win' situation for all actors involved and therefore narratively legitimised. The deployment of colonial legal instruments for territorial dispossession are used to acquire the land necessary for national green energy production. Karen Rignall [3] used Huber's analyses of the foundation role of oil in shaping the "ecology of the forces of capital" [42] to extend it to renewable energy. She cleverly used it to explain the relationship between politics and solar power infrastructure. Huber points out, and supports, the above-mentioned correlation between capital accumulation and deprivation of the locals [42]. The discourse in favour of renewable energy, which supports existing ways of life as well as the production and consumption of (green) energy with the promise of capital accumulation for certain people, will reproduce those forms of power inequalities and capitalist ecologies in ways similar to Huber's analysis of oil and ways of life [42]. Deprivation of the local people affects the most vulnerable in society (see Reference $[43,44]$ ). The region in the area of the solar project the author researched is known to be one of the poorest in Morocco. As analogous to biofuel projects (see Reference $[3,42]$ ), the land in this case study is used for green energy production. Regions such as the stone desert in Morocco, used for generating renewable energy for industrialised economies, are not only ecological but also political. The complex land tenure system in these regions, influenced by former colonial power and 'traditional' laws, traditional property rights, and use rights, facilitates land transfers from marginalised populations, such as pastoralists and nomadic groups, and forecloses their claims regarding the impact of, or benefits from, renewable energy projects (see Reference [45]).

There is a tendency to make 'worthless' and 'unused' land available for investment (see Reference $[46,47])$, which helps to legitimise investments, in this case for renewable solar energy, in order to facilitate land acquisition in rural, mostly Amazigh, regions in Morocco. In other words, the land used, such as in the research area, is constructed in narratives as unproductive, as 'empty', and unused, to pave the way for renewable energy investments that will give it value, creating new opportunities for jobs in marginal Amazigh zones. Reality shows that access to new opportunities is not usually for local people but rather for (elite) capital accumulation (see Reference $[3,43,44]$ ). As stated by Karen Rignall [3], the land surrounding Ouarzazate appears at first sight to be unused, and is described in the national and international narratives as 'wasteland'; this is also because extensive pastoralism and also nomadism have long been considered unproductive land use by Moroccan policymakers [3].

Following the argument of Ferguson's (1994) anti-politics machine, it may be suggested that LSLA projects can hide the fact that they increase the ability of control and bargaining power of the state, local leaders, NGOs, and companies (see Reference [7]). Local leaders, NGOs, companies, and the state gain access to, and control over, the rural economy, which can then reduce local options and bargaining power, especially for women. The article stresses the effects of change under large-scale land investments for green energy development. It is not a question of whether solar energy production or the generation of energy through renewable energy resources is good or bad, nor for or against investments. There is also not simply ambiguity in local people's perceptions of the Noor Ouarzazate solar project, and also of all projects in Morocco generating green energy. People do want to be part of fight against climate change and global warming by both helping to reduce $\mathrm{CO}_{2}$ emissions and generating energy in a really green manner, but therein lies the dilemma.

Funding: This research was funded by the Swiss National Science Foundation (SNSF).

Conflicts of Interest: The authors declare no conflict of interest.

\section{References}

1. Borras, S.; Hall, R.; Scoones, I.; White, B.; Wolford, W. Towards a better understanding of global land grabbing: An editorial introduction. J. Peasant Stud. 2011, 38, 209-216. [CrossRef] 
2. Fairhead, J.; Leach, M.; Scoones, I. Green grabbing: A new appropriation of nature? J. Peasant Stud. 2012, 39, 237-261. [CrossRef]

3. Rignall, K. Solar power, state power, and the politics of energy transition in pre-Saharan Morocco. Environ. Plan. A 2016, 48, 540-557. [CrossRef]

4. Ryser, S. Are green energy investments levelled by the 'new commons'? Compensations, CSR measures and gendered impacts of a solar energy project in Morocco. In Earthscan Studies in Natural Resource Management. The Commons in a Glocal World. Global Connections and Local Responses; Haller, T., Breu, T., De Moor, T., Rohr, C., Znoj, H., Eds.; Routledge: London, UK; New York, NJ, USA, 2019.

5. Moroccan Agency for Solar Energy. Plan. d'Acquisition de Terrain 2011; Projet de Complexe d'énergie solaire de 500 MW à Ouarzazate; MASEN: Rabat, Morocco, 2011.

6. Moroccan Agency for Solar Energy. Plan. d'Acquisition de Terrain 2014; Complexe NOOR d'énergie solaire à Ouarzazate-Maroc; MASEN: Rabat, Morocco, 2014.

7. Ferguson, J. The anti-politics machine: “Development" and bureaucratic power in Lesotho. Ecologist 1994, 24, 176-181. [CrossRef]

8. Rocheleau, D.; Thomas-Slayter, B.; Wangari, E. Gender and environment. In Feminist Political Ecology. Global Issues and Local Experiences; Routledge: London, UK, 1996; pp. 3-26.

9. Rocheleau, D.; Edmunds, D. Women, men and trees: Gender, power and property in forest and agrarian landscapes. World Dev. 1997, 25, 1351-1371. [CrossRef]

10. Leach, M. Rainforest Relations. Gender and Resource Use among the Mende of Gola, Sierra Leone; Smithsonian Institution Press: Washington, DC, USA, 1994.

11. Rocheleau, D.; Ross, L. Trees as tools, trees as text: Struggles over resources in Zambrana-Chacuey, Dominican Republic. Radic. J. Geogr. 1995, 27, 407-428. [CrossRef]

12. Rocheleau, D. Complex communities and emergent ecologies in the regional agroforest of Zambrana-Chacuey, Dominican Republic. Cult. Geogr. 2001, 8, 465-492.

13. Agarwal, B. The gender and environment debate: Lessons from India. Fem. Stud. 1992, 18, 119-158. [CrossRef]

14. Agarwal, B. Bargaining and gender relations: Within and beyond the household. Institute of Economic Growth, University of Delhi. Fem. Econ. 1997, 3, 1-51. [CrossRef]

15. De Schutter, $\mathrm{O}$. The agrarian transition and the 'feminisation' of agriculture. In Proceedings of the International Conference Food Sovereignty: A Critical Dialogue, New Haven, CT, USA, 14-15 September 2013; Paper No. 37.

16. Razavi, S. The Political and Social Economy of Care in a Development Context. Conceptual Issues, Research Questions and Policy Options; UNRISD: Geneva, Switzerland, 2007.

17. Abu-Lughod, L. Do Muslim Women Need Saving? Harvard University Press: London, UK, 2013.

18. Hart, D.M. Tribe and Society in Rural Morocco; Frank Cass: London, UK, 2000.

19. Sadiqi, F. Navigating the Berber culture/Islamic feminism intersection. J. World Philos. 2017, 2, $146-156$.

20. Mounib, M. Al-Dahîr 'Al-Barbarî': Akbar Ukdûba Siyâsiyya Fî Tarikh Al-Maghrib Al-Mu'asir [The 'Berber Decree': The Biggest Lie in The History of Modern Morocco]; Éditions Bouregreg: Rabat, Morocco, 2002.

21. Lugan, B. L'Histoire du Maroc. Des Origines à nos Jours; Ellipses: Paris, France, 2011.

22. Dennerlein, B. In remembering violence, negotiating change: The Moroccan equity and reconciliation commission and the politics of gender. J. Middle East Women's Stud. 2012, 8, 10-36. [CrossRef]

23. Slyomovics, S. Memory in the Middle East and North Africa: Cultural Norms, Social Practices, and Transnational Regimes. Fatna El Bouih and the work of memory, gender, and reparation in Morocco. J. Middle East Women's Stud. 2012, 8, 37-62. [CrossRef]

24. Le Forum Marocain des Métiers Verts (FMV) organisé le 9 Mai en partenariat avec le Cluster EMC-Construction21. Available online: www.construction21.org/maroc (accessed on 31 December 2018).

25. Available online: www.tgvmaroc.ma (accessed on 5 December 2018).

26. Berriane, $\mathrm{Y}$. The complexities of inclusive participatory governance: The case of Moroccan associational life in the context of the INDH. J. Econ. Soc. Res. 2010, 12, 89-111.

27. Vermeren, P. Le Maroc en Transition; La Découverte: Paris, France, 2002.

28. Bergh, S.I. The Politics of Development in Morocco. Local Governance and Participation in North Africa; I. B. Tauris \& Co.: London, UK; New York, NJ, USA, 2017. 
29. Berriane, Y. Development and Countermovements. Reflections on the Conflicts arising from the Commodification of Collective Land in Morocco. Revue Internationale de Politique de Développement 2017, 8, 247-267. [CrossRef]

30. Allal, A. 'Développement international' et 'promotion de la démocratie': À propos de la 'gouvernance locale' au Maroc. L'année du Maghreb CNRS Editions 2007, 3, 275-296. [CrossRef]

31. Bahgat, G. Morocco energy outlook: Opportunities and challenges. J. North African Stud. 2013, 18, 291-304. [CrossRef]

32. INDH. Note D'orientation Phase II 2011-2015: Mise en Oeuvre de l'Initiative Nationale pour le Développement Humain, Royaume du Maroc. Available online: www.indh.gov.ma (accessed on 1 May 2016).

33. Rignall, K. Land deal politics initiative LDPI. Theorising sovereignty in empty land: The land tenure implications of concentrated solar power in pre-Saharan Morocco. In Proceedings of the International Conference on Global Land Grabbing II, Organised by the Land Deals Politics Initiative (LDPI) and Hosted by the Department of Development Sociology Cornell University, Ithaca, NY, USA, 17-19 October 2012.

34. Rignall, K. Land, Rights, and the Practice of Making a Living in Pre-Saharan Morocco; University of Kentucky: Lexington, KY, USA, 2012.

35. Available online: www.economia.ma/content/les-coopératives-secteur-sous-perfusion-au-maroc (accessed on 30 March 2015).

36. Revue Internationale de L'économie Sociale. Available online: www.recma.org (accessed on 29 March 2016).

37. African Development Bank Group (AfDB). Projet de complexe solaire d'Ouarzazate-Phase II. Maroc. 2014. Available online: www.afdb.org/fileadmin/uploads/afdb/Documents/Environmental-and-SocialAssessments/Maroc_-_Projet_centrale_solaire_d\%E2\%80\%99Ouarzazate_II_-_R\%C3\%A9sum\%C3\%A9_ EIES.pdf (accessed on 15 September 2018).

38. Bidwell, R. Morocco under Colonial Rule: French Administration of Tribal Areas, 1912-1956; Cass: London, UK, 1973.

39. Bergh, S.I. Traditional village councils, modern associations, and the emergence of hybrid political orders in rural Morocco. Peace Rev. 2009, 21, 45-53. [CrossRef]

40. Berriane, Y. Femmes, Associations et Politique à Casablanca; Centre Jacques Berque: Rabat, Morocco, 2013.

41. Mahdi, M. Etudes Rurales. La Tribu au Secours du Développement Pastoral in La Tribu à L'heure de la Globalization; Editions de l'Ecole des hautes études en sciences sociales: Paris, France, 2009.

42. Huber, M.T. Lifeblood: Oil, Freedom, and the Forces of Capital; University of Minnesota Press: Minneapolis, MN, USA, 2013.

43. Harvey, D. The New Imperialism; Oxford University Press: New York, NJ, USA, 2003.

44. Harvey, D. A Brief. History of Neoliberalism; Oxford University Press: Oxford, UK, 2005.

45. Biofuels, Land Grabbing and Food Security in Africa; Matondi, P.; Havnevik, K.; Beyene, A. (Eds.) Zed Books: London, UK, 2011.

46. Hall, R.; Edelman, M.; Borras, S.M., Jr.; Scoones, I.; White, B.; Wolford, W. Resistance, acquiescence or incorporation? An introduction to land grabbing and political reactions 'from below'. J. Peasant Stud. 2013, 42, 467-488. [CrossRef]

47. Li, T.M. What is land? Assembling a resource for global investment. Trans. Inst. Br. Geogr. 2014, 39, 589-602. [CrossRef]

(C) 2019 by the author. Licensee MDPI, Basel, Switzerland. This article is an open access article distributed under the terms and conditions of the Creative Commons Attribution (CC BY) license (http://creativecommons.org/licenses/by/4.0/). 